\title{
Enhanced Plantlet Regeneration in Two Cacao (Theobroma cacao) Clones from Immature Inflorescence Explants
}

\author{
Jane Kahia ${ }^{1}$, Siaka Kone, Lucien Diby, and Georges Ngoran \\ World Agroforestry Center (ICRAF), Côte d'Ivoire Country Program, 08 BP \\ 2824 Abidjan 08, Côte d'Ivoire
}

Colombe Dadjo

Pan African University Institute of Basic Sciences, Technology and Innovation, P.O. Box 62000-00200, Nairobi, Kenya

\section{Christophe Kouame}

World Agroforestry Center (ICRAF), Côte d'Ivoire Country Program, 08 BP 2824 Abidjan 08, Côte d'Ivoire

Additional index words. explants, kinetin, somatic embryos, clones

\begin{abstract}
Theobroma cacao L. (cacao) is a major tropical crop, grown for its oil-rich seed, which is used in the manufacture of chocolate, its derivatives, and cosmetics. Cacao is cultivated mainly by smallholders and represents a significant export commodity for some developing countries such as Côte d'Ivoire. It is conventionally propagated by seeds, grafting, and cuttings. Somatic embryogenesis offers an alternative method for propagation where large-scale production of planting materials is possible. In the current study, the effect of different concentrations of 2, 4-dichlorophenoxyacetic acid (2, 4-D) and kinetin on induction of somatic embryogenesis and plantlet regeneration in two cocoa clones (coded as $\mathrm{C} 1$ and $\mathrm{C14}$ ) were evaluated. Flowers were collected early in the morning, sterilized, explants excised and cultured on Driver, and Kuniyuki Walnut (DKW) media supplemented with different concentrations of $2,4-D(9,10$, and $20 \mu M)$ and kinetin $(0.5,1,2.5,5,10$, and $25 \mu \mathrm{M})$ in separate experiments. The frequently used media in somatic embryogenesis of cacao [DKW supplemented with $0.022 \mu M$ thidiazuron (TDZ) and $9 \mu M 2,4-D]$ was used as a control. The results of the study showed that explants cultured on media supplemented with $10 \mu M$ 2, 4-D and $5 \mu M$ kinetin produced the highest $(28.0 \pm 1.1)$ mean number of embryos/explant in $\mathrm{C} 1$ and this was a 9-fold increase in the number of embryos compared with the control. Explants cultured on media supplemented with $10 \mu M 2,4-D$ and $2.5 \mu M$ kinetin produced the highest $(7.0 \pm$ 4.0) mean number of embryos/explant in $\mathrm{C} 14$ whereas the explants cultured on media supplemented with $20 \mu M$ 2, 4-D and $2.5 \mu M$ kinetin gave the highest $(22.0 \pm 1.7)$ mean number of embryos in clone $\mathrm{C} 1$ and $\mathrm{C} 14$. The regenerated embryos were germinated and successfully weaned in the green house with a survival rate of $70 \%$ being recorded. The paper describes an improved protocol compared with previous work in terms of embryo recovery and survival rate of the elite clones of cocoa through somatic embryogenesis. The results of the current study confirm that somatic embryogenesis of cacao clones is genotype dependent.
\end{abstract}

Cacao (Theobroma cacao, Malvaceae) is a crop of major importance for the livelihoods of small-scale farmers and ecosystems in many tropical regions. About $72 \%$ of the world's cocoa is produced in Africa, with Côte d'Ivoire being the top producer at $43 \%$ of global production (ICCO, 2015). It is produced by smallholders and five to six million rural households gain substantial income from cacao production (ICCO, 2012; WCF, 2014). Cacao is a major source of income for developing countries, especially in Côte d'Ivoire, the world's largest cocoa producer, which grows more than one-third

Received for publication 8 Feb. 2017. Accepted for publication 15 Mar. 2017.

${ }^{1}$ Corresponding author. E-mail: J.Kahia@cgiar. org. of the world's supply. The production of cocoa in Côte d'Ivoire in 2013-14 went more than 1.7 million tons (Conseil Café Cacao, 2014). However, the country has been experiencing reduction in production because of different reasons, key among them are nonimproved, ageing trees, which are susceptible to diseases and insects. Research in the country has developed high-yielding hybrid varieties and clones, but their availability is limited. Propagation and promoting access of high-performing clones to farmers to rehabilitate their old cacao orchards is of paramount importance and is key to enhancing cocoa productivity in Côte d'Ivoire. The conventional propagation by seeds poses a challenge because there is a high degree of segregation for many traits because they are highly heterozygous and thus variable in terms of agronomic performance. For this reason, clonal propagation systems such as rooted cuttings and grafting have been applied for multiplication of elite varieties (Eskes, 2005). However, these methods have some disadvantages including intensive labor and associated costs, generally low propagation rates, and an undesirable bush-like growth pattern which can occur (Figueira and Janick, 1995). Plant regeneration through somatic embryogenesis provides an alternative approach for propagation of plants. Somatic embryogenesis depends on the ability of somatic plant cells to dedifferentiate and are reprogrammed along an embryonic developmental pathway (Fehér, 2015). The main advantages of this method include the possibility of rapidly producing uniform plants of high genetic value and the clonal production of orthotropic plants with normal dimorphic architecture and taproot formation. In addition, somatic embryogenesis ensures the production of disease-free stock materials making quarantine procedures for international exchange of germplasm easy (Quainoo et al., 2012). The use of somatic embryogenesis in cacao has the potential to contribute significantly to the efforts in crop improvement, germplasm conservation, and rapid distribution of new improved varieties. This method might also facilitate genetic engineering (Corredoira et al., 2002). Propagation of elite cacao varieties through somatic embryogenesis has been achieved in a large number of genotypes, but low efficiencies and genotype dependence still present major constraints to its propagation at a commercial level (Li et al., 1998; Maximova et al., 2002, 2008). The commonly used media is the DKW (Driver and Kuniyuki, 1984) basal salts supplemented with 2, 4-D and TDZ (Ajijah et al., 2014; Li et al., 1998; Maximova et al., 2002, 2008; Quainoo and Dwomo, 2012). Lopez-Baez et al. (2000) reported the use of two auxins (2, 4-D or 2, 4, 5-T) and two cytokinins (kinetin or 2 isopentyladenine) on modified Murashige and Skoog (1962) salts. Recently, some workers have reported success in inducing cacao embryogenic cultures using kinetin and 2, 4-D (Ajijah et al., 2016; Kouassi et al., 2017). Although Kouassi et al. (2017) reported success in inducing embryogenic cultures in four of the elite cacao clones in Côte d'Ivoire, the responses were low. For the somatic embryogenesis technology to be adopted for the propagation of the Ivorian cacao clones, there is a need to work out protocols with high multiplication rates. The present study was aimed at exploring the option using various concentrations of 2, 4-D and kinetin to improve the induction of cacao somatic embryos and plantlet regeneration in the Ivorian elite cacao clones.

\section{Materials and Methods}

Plant materials. Flower buds of about 4 $5 \mathrm{~mm}$ length were collected (before 9:00 AM) from two elite clones growing in the World Agroforestry Center experimental farm in Adiopodoumé (Côte d'Ivoire). The flower buds were taken to the laboratory and subjected to 
Table 1. Effect of $9 \mu \mathrm{M} 2,4-\mathrm{D}$ and varying concentrations of kinetin $(0.5,1,5$, and $10 \mu \mathrm{M})$ on callus and embryo formation.

\begin{tabular}{lcccc}
\hline Genotypes & $\begin{array}{c}\text { 2, 4-D }(9 \mu \mathrm{M})+ \\
\text { Concentrations of } \\
\text { kinetin in } \mu \mathrm{M}\end{array}$ & $\begin{array}{c}\text { Percent } \\
\text { callus } \pm \mathrm{SE}\end{array}$ & $\begin{array}{c}\text { Percent embryogenic } \\
\text { callus } \pm \mathrm{SE}\end{array}$ & $\begin{array}{c}\text { Mean no. of } \\
\text { embryos } \pm \mathrm{SE}\end{array}$ \\
\hline $\mathrm{C} 1$ & Control & $94.0 \pm 6.0$ & $84.9 \pm 3.1 \mathrm{a}$ & $3.5 \pm 0.5 \mathrm{a}$ \\
& 0.5 & $100.0 \pm 0.0$ & $98.8 \pm 1.2 \mathrm{~b}$ & $4.5 \pm 1.3 \mathrm{a}$ \\
& 1 & $100.0 \pm 0.0$ & $100.0 \pm 0.0 \mathrm{~b}$ & $0.7 \pm 0.6 \mathrm{a}$ \\
& 5 & $94.1 \pm 5.9 \mathrm{a}$ & $0.0 \pm 5.0 \mathrm{c}$ & $0.0 \pm 0.0 \mathrm{a}$ \\
$\mathrm{C} 14$ & 10 & $100.8 \pm 2.1 \mathrm{a}$ & $0.0 \pm 0.0 \mathrm{c}$ & $0.0 \pm 0.0 \mathrm{a}$ \\
& Control & $96.6 \pm 1.9 \mathrm{a}$ & $100.0 \pm 0.0 \mathrm{~b}$ & $1.5 \pm 0.5 \mathrm{a}$ \\
& 0.5 & $100.0 \pm 0.0 \mathrm{a}$ & $100.0 \pm 0.0 \mathrm{~b}$ & $6.0 \pm 1.7 \mathrm{a}$ \\
& 1 & $100.0 \pm 0.0 \mathrm{a}$ & $8.3 \pm 8.3 \mathrm{~d}$ & $0.0 \pm 0.2 \mathrm{a}$ \\
& 5 & $100.0 \pm 0.0 \mathrm{a}$ & $45.8 \pm 5.5 \mathrm{e}$ & $6.0 \pm 0.6 \mathrm{a}$ \\
\hline
\end{tabular}

The values represent mean \pm SE of at least three replications. Means with different letters are significantly different at 5\% (Newman-Keuls test). two steps of sterilization which involved using $2 \%(\mathrm{w} / \mathrm{v})$ calcium hypochlorite for $20 \mathrm{~min}$ and rinsing four times with sterile distilled water. They were then sterilized a second time using $1 \%$ calcium hypochlorite for $10 \mathrm{~min}$ and finally rinsed four times. The flowers were then dissected using a sterile scalpel blade and the staminodes and petals extracted.

Media formulation and culture conditions. The explants (staminodes and petals) were cultured on DKW basal salts as described by Driver and Kuniyuki (1984) supplemented with different concentrations of 2, 4-D (9, 10, and 20 $\mu \mathrm{M})$ and kinetin $(0.5,1,2.5,5.10$, and $25 \mu \mathrm{M})$ in separate experiments. The control was based
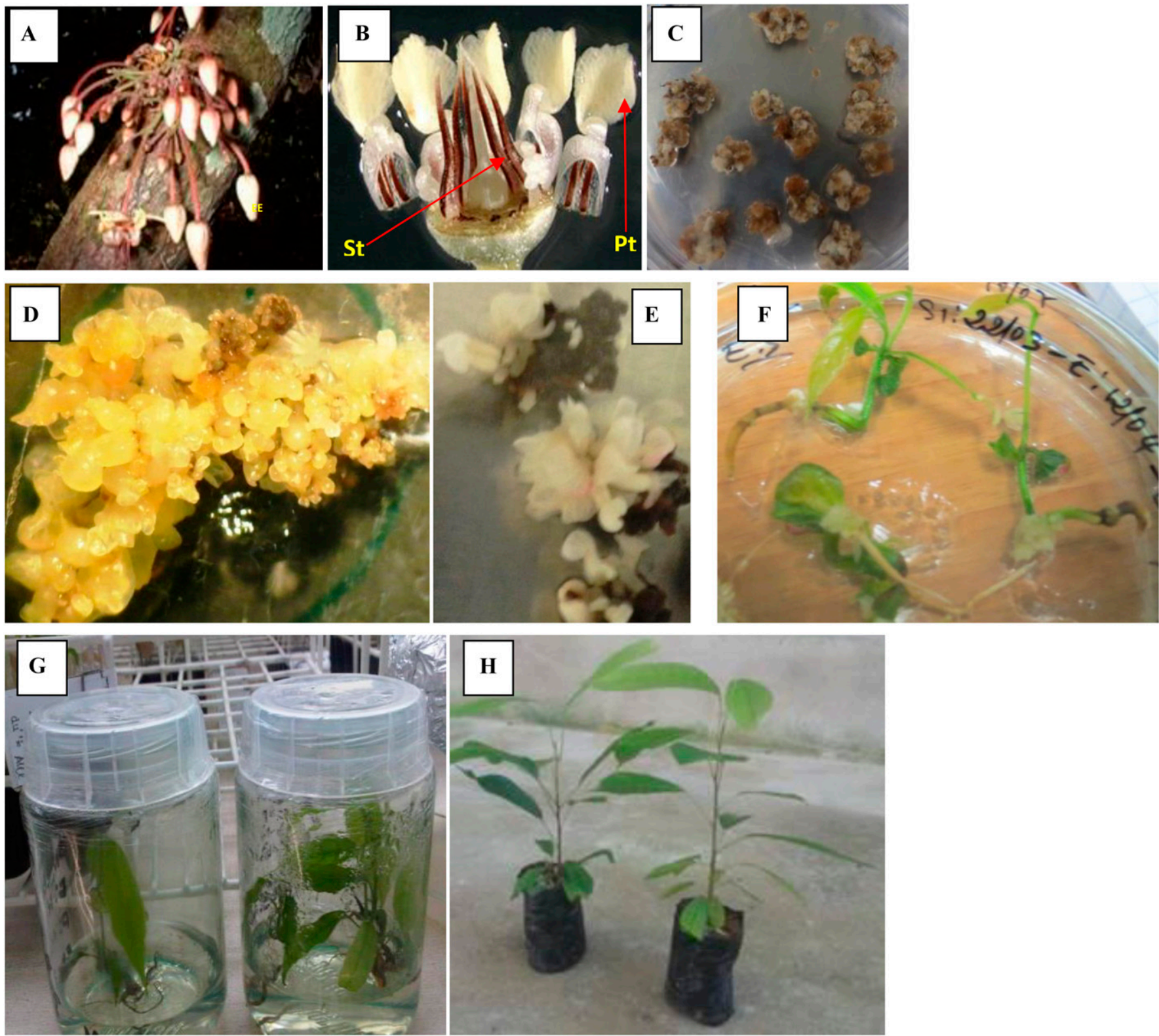

Fig. 1. Formation of somatic embryos from flower explants. (A) Flower on a cacao tree. (B) The opened flower showing the explants: (Pt) Petals and Staminodes (St). (C) Callus formed from the explants. (D) Embryos derived from the embryogenic callus. (E) Embryos at different stages. (F) Germination of embryos after 3 months. (G) Germination after 4 months. (H) Weaned plantlet. 
on the protocol developed by Li et al. (1998). The $\mathrm{pH}$ of the media was adjusted to 5.8 using $0.1 \mathrm{M} \mathrm{HCl}$ or $0.1 \mathrm{M} \mathrm{NaOH}$ and gelled with $0.2 \%(\mathrm{w} / \mathrm{v})$ phytagel before autoclaving it at $1.06 \mathrm{~kg} \cdot \mathrm{cm}^{-2}$ and $121^{\circ} \mathrm{C}$ for $20 \mathrm{~min}$.

The explants were cultured in the media under evaluation and incubated in a dark room maintained at $25 \pm 2{ }^{\circ} \mathrm{C}$. After $28 \mathrm{~d}$ on induction medium, the explants were transferred onto embryo development medium as described by Li et al. (1998) and subcultured at 4-week intervals for 3 months. The regenerated embryos were germinated in a growth room maintained at $25 \pm 2{ }^{\circ} \mathrm{C}$, cool white fluorescent light intensity of $33 \mathrm{mmol} \cdot \mathrm{m}^{-2} \cdot \mathrm{s}^{-1}$, and $16-\mathrm{h}$ photoperiod.

Data collection. Four weeks after initiation, the percent explants with callus were evaluated. This was calculated as (the number of explants producing calli/total number of explants) $\times 100$. About 3 months after initiation, the percentage of embryogenic calluses were evaluated by calculating (the number of explants producing embryos/total number of explants) $\times 100$.

Experimental design and data analysis. The experiments were laid out in a completely randomized design. Ten petri dishes, each containing 25 explants ( 250 explants/treatment) were used for all the experiments. Each trial was replicated three times. STATISTICA 7.1 was used to analyze the data. Analysis of variance was performed where applicable, and differences between means were determined by Student-Newman-Keuls multiple range test. The treatments were considered as significant at $P<0.05$.

\section{Results}

Effect of $9 \mu M$ 2, 4-D and varying concentrations of kinetin $(0.5,1,5$, and $10 \mu \mathrm{M})$ on callus and embryo formation. Culturing the explants on media supplemented with $9 \mu \mathrm{M} 2,4-\mathrm{D}$ and $0.5 \mu \mathrm{M}$ kinetin produced the highest mean number of embryos ( 4.5 and 6.0) in $\mathrm{C} 1$ and $\mathrm{C} 14$, respectively (Table 1). During the current study, it was observed that there were no embryo formed on explants cultured on media containing 5 and $10 \mu \mathrm{M}$ kinetin in $\mathrm{C} 1$ and in media containing $5 \mu \mathrm{M}$ kinetin in $\mathrm{C} 14$ (Table 1). Figure 1A-H shows the pathway of regenerating the cacao plantlets from the floral explants.

Effect of $10 \mu M$ 2, 4-D and varying concentrations of kinetin $(2.5,5$, and 25 $\mu M)$ on callus and embryo formation. Inclusion of $10 \mu \mathrm{M} 2,4-\mathrm{D}$ and kinetin in the media had a significant $(P<0.05)$ effect on embryo formation. The media supplemented with $10 \mu \mathrm{M} 2$, 4-D and $5 \mu \mathrm{M}$ kinetin produced the highest $(98.7 \%)$ embryogenic cultures and the highest (28.0) mean number of embryos/explant in C1 (Table 2). This was a 9-fold increase in the number of embryos compared with the control. On the other hand, the C14 explants cultured on media supplemented with $10 \mu \mathrm{M} 2,4-\mathrm{D}$ and $2.5 \mu \mathrm{M}$ kinetin produced 7.0 mean number of embryos per explant. It was observed that increasing the concentration of kinetin from
5 to $25 \mu \mathrm{M}$ was found to inhibit embryo formation in both $\mathrm{C} 1$ and $\mathrm{C} 14$.

Effect of $20 \mu M$ 2, 4-D and varying concentrations of kinetin $(2.5,5$, and $25 \mu M)$ on callus and embryos formation. Inclusion of $20 \mu \mathrm{M} 2,4-\mathrm{D}$ and $2.5 \mu \mathrm{M}$ kinetin in the media had a significant $(P<0.05)$ effect on embryo formation. The explants cultured on media supplemented with $20 \mu \mathrm{M} 2,4-\mathrm{D}$ and kinetin $2.5 \mu \mathrm{M}$ produced the highest (95.8 and 97.3) percentage of embryogenic cultures in $\mathrm{C} 14$ and $\mathrm{C} 1$, respectively, and the highest (22.0) mean number of embryos in both $\mathrm{Cl}$ and $\mathrm{C} 14$. Increasing the concentration of kinetin from 5 to $25 \mu \mathrm{M}$ was found to inhibit embryo formation in both $\mathrm{C} 1$ and $\mathrm{C} 14$ (Table 3).

\section{Discussion}

Auxin and cytokinins play a very important role in plant somatic embryogenesis and are required for the activation of somatic cell (Chaudhury and Qu, 2000; Jia et al., 2008; Liu et al., 2008). According to Kintzios et al. (2002), the role of cytokinins is to enhance cell division of pre-embryogenically determined cells. During the current study, kinetin was found to be more effective than TDZ in inducing somatic embryogenesis. These results are contrary to many studies which indicate that TDZ (a phenylurea type) is superior to the adenine types of cytokinins in inducing somatic embryogenesis in several plant species (Aboshama, 2011; Feng and Chen, 2014; Gill and Saxena, 1992; Kahia et al., 2016; Visser et al., 1992). In cacao, TDZ has been used by many workers (Ajijah et al., 2014; Garcia et al., 2016; Li et al., 1998; Maximova et al., 2002; Quainoo and Dwomo, 2012). An attempt to use TDZ

during this study led to low responses. However, high percent embryogenic cultures $(73 \%$ to $100 \%)$ were obtained when kinetin was used. This was much higher than those reported by Ajijah et al. (2016) (5.6\% to $66.7 \%)$ and Kouassi et al. (2017) (13\% to $14 \%$ ) when they used kinetin. Moreover, the mean number of embryos per explant was also higher (3.50-28) in the current study compared with the number $(0.7-24)$ reported by Ajijah et al. (2016). This could probably be explained by the difference in the genetic makeup of the clones used. The work being reported is similar to that of Mayati (2015) who found that kinetin was better than zeatin in somatic embryogenesis of Hevea brasiliensis RRIM 2025. However, it conflicts with the work of Chen and Chang (2001), Wongtiem et al. (2011), and Kahia et al. (2016) who reported that kinetin was inferior to other cytokinins evaluated for the induction of somatic embryos in Oncidium 'Gower Ramsey', Manihot esculenta Crantz, and Coffea Arabica, respectively. During the current study, increasing the concentration of kinetin was found to inhibit induction of somatic embryos. These results are similar to those of Ajijah et al. (2016) who observed that increasing the kinetin: 2, 4-D ratios did not significantly increase the average number of embryos in cacao. However, our results were contrary to those of Abdin and Ilah (2007) who reported that somatic embryogenesis was higher in media with high concentration of kinetin in Cychorium intybus L. During the present study, increasing the concentration of 2, 4-D from 9 to $20 \mu \mathrm{M}$ was found to increase the embryogenic calluses. These results are in contrary to those of Ali et al. (2007) and Xing et al. (2010) who

Table 2. Effect of $10 \mu \mathrm{M} 2,4-\mathrm{D}$ and varying concentrations of kinetin $(2.5,5$, and $25 \mu \mathrm{M})$ on callus and embryo formation.

\begin{tabular}{lcrrr}
\hline & $\begin{array}{c}2,4-\mathrm{D}(10 \mu \mathrm{M})+ \\
\text { Concentrations of } \\
\text { kinetin in } \mu \mathrm{M}\end{array}$ & $\begin{array}{c}\text { Percent callus } \\
\text { induction } \pm \mathrm{SE}\end{array}$ & $\begin{array}{c}\text { Percent embryogenic } \\
\text { callus } \pm \mathrm{SE}\end{array}$ & $\begin{array}{r}\text { Mean no. of } \\
\text { embryos } \pm \mathrm{SE}\end{array}$ \\
\hline $\mathrm{C} 1$ & Control & $67.0 \pm 1.6 \mathrm{a}$ & $24.9 \pm 3.1 \mathrm{a}$ & $3.5 \pm 0.5 \mathrm{a}$ \\
& 2.5 & $100.0 \pm 0.0 \mathrm{~b}$ & $93.4 \pm 3.5 \mathrm{bd}$ & $10.0 \pm 1.1 \mathrm{~b}$ \\
& 5 & $98.6 \pm 1.4 \mathrm{~b}$ & $100.0 \pm 0.0 \mathrm{~b}$ & $28.0 \pm 1.1 \mathrm{c}$ \\
$\mathrm{C} 14$ & 25 & $73.3 \pm 4.4 \mathrm{c}$ & $0.0 \pm 0.0 \mathrm{c}$ & $0.0 \pm 0.0 \mathrm{a}$ \\
& Control & $100.0 \pm 0.0 \mathrm{a}$ & $90.0 \pm 2.0 \mathrm{~d}$ & $1.5 \pm 0.5 \mathrm{a}$ \\
& 2.5 & $100.0 \pm 0.0 \mathrm{a}$ & $100.0 \pm 0.0 \mathrm{~b}$ & $7.0 \pm 4.0 \mathrm{~b}$ \\
& 5 & $76.2 \pm 0.0 \mathrm{~b}$ & $68.7 \pm 0.0 \mathrm{e}$ & $1.0 \pm 0.0 \mathrm{a}$ \\
& 25 & $93.6 \pm 1.0 \mathrm{a}$ & $0.0 \pm 0.0 \mathrm{c}$ & $0.0 \pm 0.0 \mathrm{a}$ \\
\hline
\end{tabular}

The values represent mean \pm SE of at least three replications. Means with different letters are significantly different at 5\% (Newman-Keuls test).

Table 3. Effect of $20 \mu \mathrm{M} 2$, 4-D and varying concentrations of kinetin $(2.5,5$, and $25 \mu \mathrm{M})$ on callus and embryos formation.

\begin{tabular}{lccrr}
\hline & $\begin{array}{c}2,4-\mathrm{D}(20 \mu \mathrm{M})+ \\
\text { Concn of } \\
\text { kinetin in } \mu \mathrm{M}\end{array}$ & $\begin{array}{c}\text { Percent } \\
\text { callus } \pm \mathrm{SE}\end{array}$ & $\begin{array}{c}\text { Percent embryogenic } \\
\text { callus } \pm \text { SE }\end{array}$ & $\begin{array}{r}\text { Mean no. of } \\
\text { embryos } \pm \mathrm{SE}\end{array}$ \\
\hline C1 & Control & $94.0 \pm 8.5 \mathrm{a}$ & $84.9 \pm 3.1 \mathrm{a}$ & $3.5 \pm 0.5 \mathrm{a}$ \\
& 2.5 & $100.0 \pm 0.0 \mathrm{a}$ & $97.3 \pm 2.7 \mathrm{a}$ & $22.0 \pm 1.7 \mathrm{~b}$ \\
& 5 & $100.0 \pm 0.0 \mathrm{a}$ & $93.2 \pm 6.8 \mathrm{a}$ & $0.0 \pm 0.0 \mathrm{a}$ \\
C14 & 25 & $100.0 \pm 0.0 \mathrm{a}$ & $95.8 \pm 4.2 \mathrm{a}$ & $0.0 \pm 0.0 \mathrm{a}$ \\
& $100.0 \pm 0.0 \mathrm{a}$ & $90.0 \pm 2.0 \mathrm{a}$ & $1.5 \pm 0.5 \mathrm{a}$ \\
& 2.5 & $96.3 \pm 6.4 \mathrm{a}$ & $95.8 \pm 4.2 \mathrm{a}$ & $22.0 \pm 2.3 \mathrm{~b}$ \\
& 5 & $100.0 \pm 0.0 \mathrm{a}$ & $100.0 \pm 0.0 \mathrm{a}$ & $3.0 \pm 1.1 \mathrm{a}$ \\
& 25 & $92.8 \pm 4.7 \mathrm{a}$ & $100.0 \pm 0.0 \mathrm{a}$ & $0.0 \pm 0.0 \mathrm{a}$ \\
\hline
\end{tabular}

The values represent mean \pm SE of at least three replications. Means with different letters are significantly different at 5\% (Newman-Keuls test). 
reported that lower concentration of 2, 4-D gave better response of embryogenic callus in tobacco and Erigeron breviscapus, respectively. During the current study, the embryos were germinated and successfully weaned in the greenhouse with a survival rate of $70 \%$ being recorded. This success rate reported in the current study was higher compared with that (54\%) observed by Garcia et al. (2016) while working with the Brazilian cacao clone.

The protocol developed in this study was an improvement of that reported previously by Kouassi et al. (2017) while working with the elite cacao clones in Côte d'Ivoire. These workers evaluated the effect of two $(0.25$ and $0.5 \mathrm{mg} / \mathrm{L}$ ) concentrations of kinetin and one $(1 \mathrm{mg} / \mathrm{L})$ concentration of $2,4-\mathrm{D}$ on induction of embryogenic cultures in four elite cacao clones. There was a need to evaluate a wider range of kinetin and 2, 4-D concentrations because these authors reported low responses. Furthermore, they did not report on the number of embryos from the embryogenic cultures and yet regeneration of embryos from embryogenic cultures, germination, and regeneration of plantlets is of paramount importance if the in vitro techniques have to be adopted for mass propagation of cacao. In the present study, we describe an enhanced in vitro propagation protocol for the elite Ivorian clones where higher percentage of embryogenic cultures, embryos, and plantlets were obtained than previously reported.

\section{Literature Cited}

Abdin, M.Z. and A. Ilah. 2007. Plant regeneration through somatic embryogenesis from stem and petiole explants of Indian chicory (Cichorium intybus L.). Indian J. Biotechnol. 6:250-255.

Aboshama, H.M.S. 2011. Direct somatic embryogenesis of pepper (Capsicum anпuит L.). World J. Agr. Sci. 7(6):755-762.

Ajijah, N., R.S. Hartati, Rubiyo, D. Sukma, and Sudarsono. 2016. Effective cacao somatic embryo regeneration on kinetin supplemented DKW medium and somaclonal variation assessment using SSRs markers. AGRIVITA, J. Agri. Sci. 38(1):80-92, doi: 10.17503/agrivita. v38i1.619.

Ajijah, N., Rubiyo, and Sudarsono. 2014. Callogenesis and Somatic Embryogenesis of Cacao using Thidiazuron through One Step of Callus Induction (in Indonesian). Jurnal Penelitian Pertanian Tanaman Industri 20(4):179-186. $<\mathrm{http} / / /$ www.ejurnal.litbang.pertanian.go.id/ index.php/jptip/article/view/2580/2220>

Ali, G., F. Hadi, Z. Ali, M. Tariq, and M.A. Khan. 2007. Callus induction and in vitro complete plant regeneration of different cultivars of tobacco (Nicotiana tabacum L.) on media of different hormonal concentrations. Biotechnology 6: 561-566.

Chaudhury, A. and R. Qu. 2000. Somatic embryogenesis and plant regeneration of turftype bermudagrass, effect of 6-benzyladenine in callus induction medium. Plant Cell Tissue Organ Cult. 60(2):113-120.
Chen, J.T. and W.C. Chang. 2001. Effects of auxins and cytokinins on direct somatic embryogenesison leaf explants of Oncidium 'Gower Ramsey'. Plant Growth Regulat. 34:229-232, doi: 10.1023/ A:1013304101647.

Conseil Café Cacao. 2014. Bilan de la campagne Café-Cacao 2013-2014 dans la région de la Nawa. Source: Délégation régionale du conseil café-cacao à Soubré, Côte d'Ivoire.

Corredoira, E., A.M. Veitez, and A. Ballester. 2002. Somatic embryogenesis in Elm. Ann. Bot. 89:637-644.

Driver, J.A. and A.H. Kuniyuki. 1984. In vitro propagation of Paradox walnut root stock. Hort. Sci. 19:507-509.

Eskes, A. 2005. Proceedings of the International X Production Systems: INGENIC International Workshop on Cocoa Breeding. In: F. Bekele, M. End, and A. Eskes (eds.). (INGENIC and Ghana Cocoa Board, Accra, Ghana): 1-10. 25 Aug. 2015. <http://ingenic.cas.psu.edu/ proceedings.htm $>$.

Fehér, A. 2015. Somatic embryogenesis-Stressinduced remodeling of plant cell fate. Biochim. Biophys. Acta 1849:385-402.

Feng, J.-H. and J.-T. Chen. 2014. A novel in vitro protocol for inducing direct somatic embryogenesis in Phalaenopsis aphrodite without taking explants. Sci. World J., doi: 10.1155/ 2014/263642.

Figueira, A. and J. Janick. 1995. Somatic embryogenesis in cacao (Theobroma cacao L.), p. 291310. In: S. Jain, P. Gupta, and R. Newton (eds.). Somatic embryogenesis in woody plants. Vol. 2. Kluwer Academic Publisher, The Netherlands.

Garcia, C., F. Corrêa, S. Findley, A. Almeida, M. Costa, J.C. Motamayor, R. Schnell, and J.-P. Marelli. 2016. Optimization of somatic embryogenesis procedure for commercial clones of Theobroma cacao L. Afr. J. Biotechnol. 15(36):1936-1951, doi: 10.5897/ AJB2016.15513.

Gill, R. and P.K. Saxena. 1992. Direct somatic embryogenesis and regeneration of plants from seedlings explant of peanut (Arachis hypogaea L.): Promotive role of thidiazuron. Can. J. Bot. 70:1186-1192.

International Cocoa Organization (ICCO). 2012. How many smallholders are there worldwide producing cocoa? What proportion of cocoa worldwide is produced by smallholders? 15 Jan. 2016. <http://www.icco.org >.

Jia, X.X., J.W. Zhang, H.W. Wang, and W.P. Kong. 2008. Efficient maize (Zea mays L.) regeneration derived from matured embryos in vitro. Maydica 53:239-248.

Kahia, J., P. Njenga, and M. Kirika. 2016. Improved micropropagation of plantlets from nodal explants of Anchote (Coccinia abyssinica) - A calcium and protein-rich tuber. HortScience 51:905-909.

Kintzios, S., E. Sereti, P. Bluchos, J.B. Drossopoulos, C.K. Kitsaki, and L.A. Tsakalidis. 2002. Growth regulator pretreatment improves somatic embryogenesis from leaves of squash (Cucurbita pepo L.) and melon (Cucurbita melo L.). Plant Cell Rpt. 21:(1):)1-8.

Kouassi, K.M., J. Kahia, C.N. Kouame, M.G. Tahi, and E.K. Koffi. 2017. Comparing the effect of plant growth regulators on callus and somatic embryogenesis induction in four elite Theobraoma cacao L. genotypes. HortScience 52:1-4. Li, Z., A. Traoré, S.N. Maximova, and M.J. Guiltinan. 1998. Somatic embryogenesis and plant regeneration from floral explants of cocoa (Theobroma cacao L.) using Thidiazuron. In Vitro Cell. Dev. Biol. 34:293-299.

Liu, M., J. Yang, Z. Lu, Z. Guo, X. Lin, and H. Wu. 2008. Somatic embryogenesis and plant regeneration in centipedegrass (Eremochloa ophiuroides [Munro] Hack.). In vitro cell Dev. Bio-plant 44:100-104, doi: 10.1007/ s11627-008-9115-4.

Lopez-Baez, O., J.L. Moreno-Martmnez, and S. Pacheco-Rodas. 2000. Advances in cocoa Theobroma cacao propagation by somatic embryogenesis in Mexico. In Abstr. 3 \# Ingenic Workshop on the New Technologies and Cocoa Breeding, Kota Kinabalu, Malaysia.

Maximova, S.N., L. Alemanno, A. Young, N. Ferrière, A. Traoré, and M.J. Guiltinan. 2002. Efficiency, genotypic variability, and cellular origin of primary and secondary somatic embryogenesis of Theobroma cacao L. In Vitro Cell. Dev. Biol. Plant 38:252-259.

Maximova, S.N., A. Young, S. Pishak, and M.J. Guiltinan. 2008. Field performance of Theobroma cacao L. plants propagated via somatic embryogenesis. In Vitro Cell. Dev. Biol. Plant 44:487-493.

Mayati, C.H.N. 2015. Effects of Zeatin and Kinetin on in vitro Regeneration of Hevea brasiliensis RRIM 2025. Journal of Rubber Research 18(3): 127-138.

Murashige, T. and E. Skoog. 1962. A revised medium for rapid growth and bioassays with tobacco tissue cultures. Physiol. Plant. 15:473497.

Quainoo, A.K. and B.I. Dwomo. 2012. The effect of TDZ and 2, 4-D concentrations on the induction of somatic embryo and embryogenesis in different cocoa genotypes. Journal of Plant Studies 1(1):72-77.

Quainoo, A.K., G. Nyarko, F. Davrieux, G. Piombo, J.M. Bouvet, J.A. Yidana, A.H. Abubakari, G.K. Mahunu, F.K. Abagale, and F.A. Chimsah. 2012. Determination of biochemical composition of shea (Vitellaria paradoxa) nut using near infrared spectroscopy (NIRS) and gas chromatography. IJBPAS 1(2):84-98.

Visser, C., J.A. Qureshi, R. Gill, and P.K. Saxena. 1992. Morphoregulatory role of thidiazuron: Substitution of auxin and cytokinins requirement for the induction of somatic embryogenesis in geranium hypocotyl cultures. Plant Physiol. 99:1704-1707.

Wongtiem, P., D. Courtois, B. Florin, M. Juchaux, D. Peltier, P. Broun, and J.P. Ducos. 2011. Effects of cytokinins on secondary somatic embryogenesis of selected clone Rayong 9 of Manihot esculenta Crantz for ethanol production. Afr. J. Biotechnol. 10(9):1600-1608.

World Cocoa Foundation (WCF). 2014. Cocoa market update. Washington DC. 15 Jan. 2016. $<$ http://www.worldcocoafoundation.org $>$.

Xing, Z.Y., Y.H. Yuan, L.F. Wang, and L.P. Zheng. 2010. Regenerating plants from in vitro culture of Erigeron breviscapus leaves. Afr. J. Biotechnol. 9:4022-4024. 